\title{
WEB INFORMATION, ACCESSIBILITY AND MUSEUM OWNERSHIP
}

\begin{abstract}
When planning a holiday, the pre-trip phase is crucial for persons with disabilities (PWDs) and their families. The potential of the World Wide Web to disseminate information devoted to PWDs and regarding the accessibility of tourism attractions is great. However, the propensity to disseminate information online varies depending on the type of organization. This paper assesses the impact of the ownership of museums in Tuscany (central Italy) on whether a museum has online information specifically for PWDs. Tuscany is a frequent destination for domestic and foreign tourists and the online communication of museums addresses a large and heterogeneous audience. The empirical analysis shows that public museums tend to deliver more information for PWDs, compared to private and ecclesiastical museums.
\end{abstract}

Keywords. Accessible tourism; disability; social inclusion; web marketing; websites.

\section{Introduction}

This paper focuses on the online information regarding museums ${ }^{1}$ located in Tuscany, Italy, and related to persons with disabilities (PWDs). The empirical analysis studies the relationship between the ownership of the museums, the services provided, and the information available on the web regarding PWDs and their families. In particular, the empirical analysis compares public museums with non-public museums in terms of the extent of communication devoted to PWDs.

Broadly speaking, the web is an essential information resource for those living in advanced countries (OECD, 2015) and many families make their travel plans through the $w_{e} b^{2}$. There is a clear reason for this: the web is free, it facilitates and accelerates the acquisition of information, and does not require physical movement. Gathering information on the web therefore has clear benefits for PWDs and their families. It is thus first important to analyse the characteristics of tourism websites and to assess their ability to adequately inform PWDs regarding the accessibility and additional 
services and, second, to explore whether such an ability is correlated with the institutional characteristics of the tourism structures.

The paper is organized as follows. Section 2 is a brief review of the relevant literature regarding the relationship between PWDs, tourism activities and information; in addition, Section 2 discusses the propensity of public and private museums to disseminate information on PWDs. Section 3 explains why Tuscany is an appropriate environment to empirically explore the issues raised in this paper. Section 4 describes the data collection and presents some descriptive statistics. Section 5 covers the empirical analysis and the main findings, and Section 6 presents the results of a telephone survey which considered museums without online information on PWDs. Finally, Section 7 discusses the implications of the main findings.

\section{A brief literature review}

Since the late 1970s, tourism scholars have investigated the potential of persons with mental or physical impairments to become active and autonomous tourists (see, for example, Finch, 1979). Given the variety of disabilities and tourism experiences, the research has covered several topics (Darcy, 2002). Today, the literature on PWDs and their families adopts a broad approach without necessarily focusing on the "material" characteristics of the trip, the places of interest and the accommodation facilities (Shelton and Tucker, 2005), but also considering a combination of environmental and cultural elements (Yau, McKercher and Packer, 2004; Paker, Mckercher and Yau, 2007; Buhalis and Darcy, 2010; Blichfeldt and Nicolaisen, 2011). In addition, the condition of disabled tourists needs to be contextualized from the wider perspective of social inclusion (Darcy, 2001; Darcy, Cameron and Pegg, 2010; Buhalis, Darcy and Ambrose, 2012; Kastenholz, Eusébio and Figueiredo, 2015).

Social inclusion is defined as "the process of improving the terms of participation in society for people who are disadvantaged (...) through enhanced opportunities, access to resources, voice and respect for rights" (United Nations, 2016). In the case of PWDs, the instruments of social inclusion tend to remove the physical, economic and cultural barriers that prevent an effective visibility and participation in professional and leisure activities. In addition, the visibility and representation of PWD needs and requirements facilitate policies designed for PWDs and their families (Schriner, 2001). 
Regarding tourism, the participation of disadvantaged people means both the opportunity to access tourism sites and to be visible and recognized, in order to be the recipients of information regarding the possible destinations. In fact, the availability and exchange of information are fundamental for choosing, planning and enjoying the tourism experience.

The dissemination of information regarding accessibility is thus crucial for PWDs. The first contact that PWDs and their families have with the places of interest occurs with the promotional material, such as brochures and websites. The presentation of the characteristics of the tourist attractions exerts a strong influence on the choice of destination, and the surveys conducted on this (for example, Eichhorn, Miller, Michopoulou, and Buhalis, 2008) confirm that this effect is greater for PWDs. While the academic literature widely recognizes the importance of (web) information for disabled tourists, no empirical study has explored how different organizations deal with this issue. In particular, no study analyzes and compares the ability of private and public museums to disseminate online information on accessibility.

In reality, tourism studies and cultural economics have frequently compared public and private museums and other institutions in terms of the organization, management, pricing decisions, and provision of cultural services (see, among others, O'Hagan, 1995; Schuster, 1998; Frey and Meier, 2011). In fact, the structure of museum ownership has often been recognized as the crucial institutional factor that affects their incentives and operations (Frey and Pommerehne 1989; Benhamou 1998). For example, Frey and Pommerehne (1989) maintain that, since public contributions cover the budget of public museums, such museums have few incentives to generate alternative sources of income and thus to satisfy public preferences. In particular, when public museums are owned and controlled by government entities, they may be inefficient in adopting strategies that expand the potential audience.

In contrast, private museums rely more on private funding and revenue sources; and therefore have greater incentives to engage in efficient practices that ensure financial sustainability. Private museums may thus strive to gain recognition from their various stakeholders, because the preferences of a larger group of people are taken into account (Frey and Meier 2006).

Therefore, private museums are probably more interested than public structures in increasing the quantity and quality of information in order to attract more categories of visitors. This also suggests that museums owned by private institutions are more likely 
to satisfy the demand for information expressed by PWDs and their families than public museums.

This hypothesis relies on a standard economic argument; however, it needs to be adequately contextualized within the institutional and regulatory framework. In most countries, the matter of accessible tourism is subject to the competencies of national and local authorities. In Italy, for example, both national and regional governments have the power to legislate, within the framework of European Directives, on the accessibility to tourism sites. The other administrative institutions, that is provinces and municipalities, are then required to follow such regulations ${ }^{3}$. At the same time, national and local institutions can be the owners of museums. It would be surprising if public institutions adopted policies aimed at increasing the social inclusion of PWDs within the tourism industry, and then failed to implement and communicate the results of the same policies when they act as owners and administrators of tourist sites. This thus suggests that public museums (owned by the central state, regions, provinces and municipalities) would be more, and not less attentive, to the needs and interests of PWDs compared to private museums. In addition, private initiatives aimed at promoting the social inclusion of PWDs are unlikely in the absence of a clear regulatory framework and a general context where public structures are aware of their special responsibility, to ensure accessibility in the tourism industry (Darcy, Cameron and Schweinsberg, 2012).

For these reasons, the relationship between museum ownership and the characteristics of the information aimed at specific categories of visitors cannot be easily predicted and is definitely an empirical question. Unfortunately, few studies have explored this theme. This paper fills this gap by considering the Italian context.

\section{The context: Italy and Tuscany}

Traditionally, Italian museums have mainly been public institutions managed by national or local government authorities. Since the end of the last century, several reforms have enabled outsourcing and new, more decentralized organizational arrangements for public museum management. At the same time, private museums have multiplied (Bertacchini, Dalle Nogare and Scuderi 2018).

This paper concentrates on the museums located in Tuscany and analyses the information regarding the accessibility for PWDs that museums make available on the 
web. There are two main reasons why Tuscany is an appropriate area for investigating these themes.

Firstly, Tuscany has a large number of museums (675) that are characterized by heterogeneity in ownership structure. The large sample of this paper (585 out of 675 total museums) permits both descriptive and inferential analyses. The aim of the empirical analysis is to explore the possible correlations between the institutional characteristics of the museums and the level of inclusion of PWDs and their families in the museum information strategies. The present paper is thus a step forward with respect to previous studies on accessible tourism, because it attempts to both describe and explain the differences across tourist attractions in terms of inclusion policies.

Secondly, Tuscany is an important destination in relation to both domestic and foreign tourism. According to the regional government in Tuscany (Regione Toscana, 2017), $7,121,948$ foreign and 5,845,383 domestic tourists visited Tuscany in 2016. In addition, the Italian Ministry of Cultural Heritage and Activities and Tourism (hereafter, MIBACT) reported that Tuscan museums received 7,042,018 visitors in 2017 (MIBACT, 2018). The international character of tourism in Tuscany increases the importance of trip planning, which is a crucial phase in the tourist experience and largely determines the choice of the destination (Fodness and Murray, 1997; Vogt and Fesenmaier, 1998; Gursoy and McCleary, 2004; Bieger and Laesser, 2004). For PWDs and their families, planning entails gathering information on the feasibility of the trip. In addition, the abundance of foreign tourists in Tuscany means that a broad and heterogeneous community have access to the information resources of the places of interest.

\section{Data and descriptive statistics}

We collected the data on museums in Tuscany in January 2018, using two data sources. First, we used the website Museo Italia (http://www.museionline.info/), which was created by Neosintesis (a private company) in 2013 to disseminate information about public and private Italian museums. We then crosschecked the data with the database of the MIBACT, available at http://www.beniculturali.it. We included in the sample all the institutions that Museo Italia and MIBACT define as a "museum", be they private or public, non-profit or profit oriented. In January 2018, Museo Italia included more than 4000 museums, 675 of which were in Tuscany. Museo Italia describes each museum on separate web pages, including various types of information (location, 
ownership, price, etc.), which is particularly useful if the museum does not have its own website. We completed the information using the active websites of each museum. We considered only the places of interests with regulated access, that is, we did not consider places of interest located in squares, streets, parks etc. In addition, we considered museums located in a church only if the access was regulated (for example, if a maximum number of visitors were admitted). After these controls, the sample includes 585 observations.

According to Museo Italia and MIBACT, museum owners include the central state (national museum), a region (regional museums), a province (provincial museum), a municipality (municipal museum), a private company (private museums), a foundation (foundation museum), or the Catholic Church (ecclesiastical museum). Table 1 shows the museum ownership sorted by the provincial distribution of museums in Tuscany (given the low number of regional and provincial museums, they have been aggregated).

Table 1. Museums by province and ownership in Tuscany, January 2018.

\begin{tabular}{|c|c|c|c|c|c|c|c|}
\hline \multirow[b]{2}{*}{ Province } & \multicolumn{7}{|c|}{ Ownership } \\
\hline & Private & Ecclesiastical & Foundation & Municipal & Provincial/Regional & National & Total \\
\hline Arezzo & 4 & 7 & 3 & 30 & 1 & 8 & 53 \\
\hline Florence & 30 & 45 & 16 & 58 & 3 & 27 & 179 \\
\hline Grosseto & 4 & 4 & 1 & 34 & 0 & 3 & 46 \\
\hline Livorno & 5 & 6 & 2 & 22 & 1 & 3 & 39 \\
\hline Lucca & 7 & 3 & 7 & 24 & 4 & 2 & 47 \\
\hline Massa-Carrara & 3 & 4 & 2 & 11 & 0 & 4 & 24 \\
\hline Pisa & 12 & 11 & 5 & 25 & 0 & 8 & 61 \\
\hline Pistoia & 8 & 4 & 5 & 14 & 1 & 4 & 36 \\
\hline Prato & 3 & 5 & 4 & 9 & 1 & 3 & 35 \\
\hline Siena & 8 & 17 & 9 & 33 & 0 & 7 & 74 \\
\hline Total & 85 & 106 & 54 & 260 & 11 & 69 & 585 \\
\hline
\end{tabular}

Municipal councils own the majority of public museums. Many museums are located in the province of Florence, although the province of Siena has the highest number of museums per capita (2.73 museums per 10000 inhabitants).

Table 2 shows the percentage of museums with free entry and the average ticket price sorted by ownership. Table 2 also shows the percentage of museums with their own website, and two "quality indexes": communication and service. The communication 
quality index measures the number of contacts found on Museo Italia and MIBACT websites: telephone number, fax number, e-mail address and social network account. The service quality index measures the number of ancillary services: bookshop, guided tours, temporary exhibitions, archive service, library, parking, and didactic services. To facilitate comparisons, both indexes are normalized to $[0,1]$ interval. The third part of Table 2 shows the percentage of museums with information for PWDs (PWD info), for example regarding accessibility (as well as information about inaccessibility) or price reductions for PWDs. Finally, PWD services report the percentage of museums with additional services for PWDs (for instance, a wheelchair service or the direct assistance of museum staff).

Table 2. Ownership, price, information for PWDs and PWD services of museums in Tuscany, January 2018.

\begin{tabular}{lccccccc}
\hline & \multicolumn{7}{c}{ Ownership } \\
\hline Characteristics & Private & Ecclesiastical & Foundation & Municipal & Provincial/Regional & National & Total \\
\hline Free access (\%) & 57.65 & 34.90 & 51.85 & 50.77 & 54.54 & 37.68 & 47.52 \\
Average price & 2.69 & 3.78 & 3.03 & 2.30 & 3.45 & 3.82 & 2.89 \\
\hline Website (\%) & 57.65 & 49.06 & 68.52 & 24.61 & 63.63 & 39.13 & 40.34 \\
Comm. quality & 0.56 & 0.52 & 0.65 & 0.42 & 0.57 & 0.50 & 0.49 \\
Service quality & 0.54 & 0.42 & 0.71 & 0.41 & 0.60 & 0.48 & 0.47 \\
\hline PWD info (\%) & 15.29 & 38.68 & 30.19 & 22.69 & 54.54 & 28.98 & 26.54 \\
PWD serv. (\%) & 1.18 & 0 & 3.70 & 1.15 & 9.09 & 5.79 & 1.88 \\
\hline
\end{tabular}

Sources: Museo Italia and MIBACT. Average price (in Euros), communication quality and service quality are means. The average price also considers the museums with free access.

Most private museums have free access; thus, the resulting average price is low, although higher than the price charged by municipal museums. On the other hand, ecclesiastical and national museums have the lowest percentage of free access and the highest average price. Sixty per cent of museums do not have their own website, although the percentage varies across different ownership structures (from $75.39 \%$ of municipal museums to $31.48 \%$ of foundation museums). The museums owned by foundations have the highest communication and service quality index. A little over a quarter of museums (26.54\%) have specific information for PWDs and their families. Most of this information regards accessibility (or inaccessibility) to the places of interest. Only 13 out of the 85 private museums provide information regarding PWDs, while the percentage of provincial/regional museums providing this information is 3.6 times 
higher. Only 11 museums (1.88\%) provide additional information for PWDs, regarding, for example, possible assistance by museum staff.

There is no apparent correlation between the percentage of museums with their own website and the availability of information for PWDs. For example, $57.65 \%$ of private museums have their own website, but just $15.29 \%$ provide information for PWDs. Unlike what Cloquet et al. (2017) observed in Cornwall, no museum websites in Tuscany display images depicting PWDs or, broadly speaking, disability 4 .

Note that Table 2 shows the characteristics that the museums claim that they possess. If a museum does not reveal information regarding PWDs and services for PWDs, we cannot ascertain the effective absence of accessibility and additional services. In other words, the amount and the characteristics of the information published online is not necessarily an accurate portrayal of the actual characteristics of the museum sites. Of course, the lack of information about services and facilities denotes, per se, a poor knowledge of how PWDs and their families plan trips to museums.

The descriptive analysis of this section shows that information on accessibility to tourism facilities is, broadly speaking, scarce, which therefore confirms the results of Clear (2000), Darcy and Taylor (2009), Oliver and Barnes (2010) and Cloquet et al. (2017). However, a simple descriptive analysis cannot clarify whether institutional factors affect the quality of information dedicated to PWDs. For this reason, the next section proposes a more sophisticated analysis based on a probit model.

\section{Empirical analysis and main results}

This section presents a probit analysis to assess whether the institutional characteristics of museums are correlated with the presence of information and specialist assistance devoted to PWDs. In the probit analysis, a response variable $Y$ can have only two possible outcomes, 1 and 0 . A vector of regressors $X$ are assumed to influence $Y$. In symbols, the model is

$$
\operatorname{Pr}(Y=1 \mid X)=\phi\left(X^{\top} \beta\right)
$$

where $\operatorname{Pr}$ denotes probability, and $\phi$ is the Cumulative Distribution Function of the standard normal distribution. The parameters $\beta$ are estimated by maximum likelihood. 
Our analysis considers two outcomes: 1) whether or not the museum has information regarding PWDs; 2) whether or not the museum provides services for PWDs. The ownership of the museums (national, provincial/regional, municipal, private, foundation, ecclesiastical) is the main explicative variable. We also identified two particular museum categories using the following dummy variables: "religious", if the museum is located within an area that is or was a place of worship (10.8\%), and "archaeological", if the museum is located within an archaeological site (11.8\%). The religious museums are not necessarily owned by the Catholic Church.

We also included the following control variables in the regressions: whether or not the museum is in the capital of a province (capital); the provincial income per capita (income); the price of the ticket (price); whether or not the museum has a proprietary website (website); the quality of communication (communication quality); the quality of services (service quality). As noted in the previous section, communication quality and service quality do not include information and services devoted to PWDs, which are the dependent variables.

Table 3 shows the results of the probit analysis. The regression I includes all the observations of the sample. The regression II considers only two types of museums ownership: public (national, provincial/regional and municipal) and non-public (ecclesiastical, private, foundation). Columns 3 and 4 in Table 3 replicate the regressions separately for public and non-public museums. Table 3 does not show the variable foundation due to collinearity problems.

Table 3. Probit analysis. Dependent variable: information for PWDs.

\begin{tabular}{lllll}
\hline & I & II & Public & Non-public \\
\hline National & 0.196 & & & \\
Provincial/Regional & $(0.293)$ & & & \\
Municipal & $0.998^{* *}$ & & & \\
& $(0.494)$ & & & \\
Private & $0.539^{* *}$ & & & \\
& $(0.249)$ & & & \\
Ecclesiastical & -0.306 & & & \\
& $(0.273)$ & & & \\
Public & $0.532^{*}$ & & & \\
& $(0.274)$ & & & \\
Archeological & & $0.376^{* * *}$ & & \\
& & $(0.144)$ & & \\
Religious & $-0.654^{* *}$ & $-0.621^{* *}$ & -0.446 & $(0.340)$ \\
& $(0.302)$ & $(0.290)$ & $1.197^{* * *}$ & 0.259 \\
Capital & 0.247 & $0.552^{* *}$ & $(0.388)$ & $0.265)$ \\
& $(0.239)$ & $(0.214)$ & -0.050 \\
& 0.089 & 0.039 & 0.120 & $(0.209)$
\end{tabular}




\begin{tabular}{|c|c|c|c|c|}
\hline Income & $\begin{array}{l}0.158^{* * *} \\
(0.054)\end{array}$ & $\begin{array}{l}0.139^{* * *} \\
(0.053)\end{array}$ & $\begin{array}{l}0.149^{* *} \\
(0.079)\end{array}$ & $\begin{array}{l}0.092 \\
(0.076)\end{array}$ \\
\hline Price & $0.114^{* * *}$ & $0.109^{* * *}$ & $0.101^{* \star *}$ & $0.121^{\star * *}$ \\
\hline & $(0.021)$ & $(0.020)$ & $(0.030)$ & $(0.029)$ \\
\hline Website & $\begin{array}{l}0.673^{* * *} \\
(0.205)\end{array}$ & $\begin{array}{l}0.663^{\star \star *} \\
(0.202)\end{array}$ & $\begin{array}{l}1.114^{* \star *} \\
(0.282)\end{array}$ & $\begin{array}{l}0.027 \\
(0.306)\end{array}$ \\
\hline Communication quality & $\begin{array}{l}-0.031 \\
(0.123)\end{array}$ & $\begin{array}{l}-0.020 \\
(0.119)\end{array}$ & $\begin{array}{l}-0.150 \\
(0.177)\end{array}$ & $\begin{array}{l}0.268 \\
(0.178)\end{array}$ \\
\hline Service quality & $\begin{array}{l}0.169^{* * *} \\
(0.056)\end{array}$ & $\begin{array}{l}0.152^{* * *} \\
(0.055)\end{array}$ & $\begin{array}{l}0.245^{* * *} \\
(0.075)\end{array}$ & $\begin{array}{l}0.002 \\
(0.086)\end{array}$ \\
\hline Constant & $\begin{array}{l}-5.070^{* * *} \\
(1.185)\end{array}$ & $\begin{array}{l}-4.411^{* * *} \\
(1.133)\end{array}$ & $\begin{array}{l}-5.572^{* * *} \\
(1.660)\end{array}$ & $\begin{array}{l}-3.451^{* * *} \\
(1.639)\end{array}$ \\
\hline $\mathrm{N}$ & 585 & 585 & 340 & 230 \\
\hline $\operatorname{LR} \chi^{2}$ & 214.33 & 199.49 & 159.43 & 54.03 \\
\hline Pseudo $\mathrm{R}^{2}$ & 0.317 & 0.295 & 0.417 & 0.191 \\
\hline
\end{tabular}

The first regression (I) shows that the probability of having information regarding PWDs increases if the museums are regional/provincial or municipal. The effect is positive but less significant in the case of ecclesiastical museums. If museums are located within an archeological area, the probability of information for PWDs decreases by $65.4 \%$. Using broader categories of museum ownership, the second regression (II) shows that the probability of information for PWDs increases by $37.6 \%$ if the museums are public. Each additional euro of the ticket price increases the probability of information by $10-$ $11 \%$ in all regressions, while the quality of communication is not correlated with the availability of information regarding PWDs. Finally, income per capita, having a website, and service quality exert a positive and significant effect on the probability of information for PWDs, although the significance of these variables vanishes in the case of non-public museums. Broadly speaking, the coefficients in the last column of Table 3 are scarcely significant due to the heterogeneity of non-public museums.

The dependent variable in Table 4 is the availability of online information regarding services and assistance to PWDs and their families.

Only 11 out of 585 museums offer such information. These museums are located in Florence (Alinari Photography Museum, Horne Museum, National Museum of Bargello, Davanzati Palace, Cenacolo of Sant'Apollonia, Marino Marini Museum), Lastra a Signa (Enrico Caruso Museum), Anghiari (Museum of the Battle of Anghiari), and Lucca (Botanical Museum, National Museum of Villa Guinigi, National Museum of Mansi Palace). Table 4 does not show the regressions sorted by public and non-public 
museums, because several museum categories do not provide any PWD service, thus making a probit analysis worthless.

Table 4. Probit analysis. Dependent variable: services for PWDs.

\begin{tabular}{|c|c|c|}
\hline & I & II \\
\hline National & $\begin{array}{c}0.209 \\
(0.452)\end{array}$ & \\
\hline Provincial/Regional & $\begin{array}{c}0.687 \\
(0.644)\end{array}$ & \\
\hline Municipal & $\begin{array}{c}0.061 \\
(0.453)\end{array}$ & \\
\hline Private & $\begin{array}{c}-0.460 \\
(0.595)\end{array}$ & \\
\hline Ecclesiastical & - & \\
\hline Public & & $\begin{array}{l}0.631^{*} \\
(0.326)\end{array}$ \\
\hline Archeological & - & - \\
\hline Religious & $\begin{array}{c}0.539 \\
(0.473)\end{array}$ & $\begin{array}{l}-0.090 \\
(0.498)\end{array}$ \\
\hline Capital & $\begin{array}{c}0.672^{*} \\
(0.385)\end{array}$ & $\begin{array}{c}0.768^{*} \\
(0.347)\end{array}$ \\
\hline Income & $\begin{array}{c}0.213 \\
(0.138)\end{array}$ & $\begin{array}{c}0.177 \\
(0.127)\end{array}$ \\
\hline Price & $\begin{array}{c}0.007 \\
(0.044)\end{array}$ & $\begin{array}{l}-0.008 \\
(0.040)\end{array}$ \\
\hline Website & $\begin{array}{c}0.542 \\
(0.518)\end{array}$ & $\begin{array}{c}0.557 \\
(0.467)\end{array}$ \\
\hline Communication quality & $\begin{array}{c}0.079 \\
(0.247)\end{array}$ & $\begin{array}{c}-0.065 \\
(0.224)\end{array}$ \\
\hline Service quality & $\begin{array}{c}0.045 \\
(0.120)\end{array}$ & $\begin{array}{c}0.101 \\
(0.117)\end{array}$ \\
\hline Constant & $\begin{array}{c}-12.796 \\
(11.185)\end{array}$ & $\begin{array}{c}-12.301 \\
(10.133)\end{array}$ \\
\hline $\mathrm{N}$ & 411 & 516 \\
\hline $\operatorname{LR} \chi^{2}$ & 26.13 & 24.91 \\
\hline Pseudo $\mathrm{R}^{2}$ & 0.249 & 0.228 \\
\hline
\end{tabular}

*Significant at $10 \%$ level. ${ }^{*}$ Significant at $5 \%$ level. $* * *$ Significant at $1 \%$ level. The coefficients are marginal effects. Standard errors in parentheses. In regression I, the probit analysis drops the variables ecclesiastical and archeological, because the museums owned by the Church and the archeological sites never provide assistance to PWDs. In regression II, the probit regression drops the variable archeological for the same reason.

The low number of museums that provide services of PWDs reduces the significance of the model. However, the coefficient of public museums is still positive and significant: in a public museum there is a $63 \%$ increased probability of services for PWDs compared to private museums. Also the museums located in the provincial capitals have a higher probability of offering services for PWDs. Neither archeological sites nor ecclesiastical museums claim to offer assistance or service for PWDs. 
Broadly speaking, public museums perform better, in terms of the amount of information dedicated to PWDs and their families, compared to the museums owned by private companies, foundations and the Catholic Church. In particular, municipal, provincial and regional museums perform the best in terms of the provision of information regarding accessibility and services for PWDs.

\section{Museums without online information on PWDs: telephone survey}

Nearly two-thirds of museums in Tuscany do not provide online information aimed at PWDs. These figures do not necessarily mean that accessibility is not guaranteed. In other words, some museums may fail to communicate the degree of accessibility for disabled people. Therefore, this section shows the results of a telephone survey including all the museums that do not display online information for PWDs. We called all 430 museums that fall in this category to ask whether the museum was accessible to visitors using a wheelchair. For the sake of simplicity, we did not explore other types of accessibility. We were unable to contact four museums, while the respondents of three museums were unable to provide reliable information regarding accessibility. Thus, the final sample consists of 423 observations. The respondent was an operator/receptionist in most cases, thus we were unable to conduct a more detailed interview, regarding, for example, the reasons for the absence of online information. We assume that a museum without online information on accessibility is not accessible for PWDs (we will return to this assumption in endnote 4 ).

Table 5 shows the results of a probit analysis based on the survey. The dependent variable of the probit analysis is equal to 1 if a museum is not accessible to PWDs, equal to 0 if it is. Therefore, in the first case, the museum confirms the information that we collected online; in the second case, the museum does not confirm the online information. As in Section 3, the regression II considers only two types of museums: public (national, provincial/regional and municipal) and non-public (ecclesiastical, private, foundation).

Table 5. Probit analysis. Dependent variable: confirmation of online information.

\begin{tabular}{lcc}
\hline & I & II \\
\hline National & 0.469 & \\
& $(0.465)$ &
\end{tabular}




\begin{tabular}{|c|c|c|}
\hline \multicolumn{3}{|l|}{ Provincial/Regional } \\
\hline Municipal & $\begin{array}{c}1.224^{* * *} \\
(0.436)\end{array}$ & \\
\hline Private & $\begin{array}{c}0.443 \\
(0.413)\end{array}$ & \\
\hline Ecclesiastical & $\begin{array}{c}0.460 \\
(0.467)\end{array}$ & \\
\hline Public & & $\begin{array}{l}0.618^{* *} \\
(0.257)\end{array}$ \\
\hline Archeological & $\begin{array}{l}-0.547^{*} \\
(0.303)\end{array}$ & $\begin{array}{c}-0.509^{*} \\
(0.290)\end{array}$ \\
\hline Religious & $\begin{array}{c}0.003 \\
(0.441)\end{array}$ & $\begin{array}{c}0.050 \\
(0.402)\end{array}$ \\
\hline Capital & $\begin{array}{l}0.511^{*} \\
(0.295)\end{array}$ & $\begin{array}{c}0.355 \\
(0.274)\end{array}$ \\
\hline Income & $\begin{array}{l}-0.001 \\
(0.001)\end{array}$ & $\begin{array}{l}-0.001 \\
(0.001)\end{array}$ \\
\hline Price & $\begin{array}{c}-0.078^{* *} \\
(0.038)\end{array}$ & $\begin{array}{c}-0.072^{* *} \\
(0.037)\end{array}$ \\
\hline Website & $\begin{array}{c}0.212 \\
(0.423)\end{array}$ & $\begin{array}{c}0.211 \\
(0.419)\end{array}$ \\
\hline Communication quality & $\begin{array}{c}0.038 \\
(0.261)\end{array}$ & $\begin{array}{c}0.013 \\
(0.250)\end{array}$ \\
\hline Service quality & $\begin{array}{l}-0.041 \\
(0.121)\end{array}$ & $\begin{array}{c}0.027 \\
(0.113)\end{array}$ \\
\hline Constant & $\begin{array}{c}2.347 \\
(2.061)\end{array}$ & $\begin{array}{c}2.339 \\
(1.991)\end{array}$ \\
\hline $\mathrm{N}$ & 418 & 423 \\
\hline $\operatorname{LR} \chi^{2}$ & 18.46 & 13.97 \\
\hline Pseudo $\mathrm{R}^{2}$ & 0.119 & 0.091 \\
\hline $\begin{array}{l}\text { Significant at } 10 \% \text { lev } \\
\text { narginal effects. Stand } \\
\text { egression I, the probit } \\
\text { Provincial/Regional, bec } \\
\text { oy provinces or regions }\end{array}$ & $\begin{array}{l}\text { Tignifican } \\
\text { The } \\
\text { rors in } \\
\text { sis drop } \\
\text { all the } m\end{array}$ & $\begin{array}{l}\text { \% level } \\
\text { ients are } \\
\text { theses. In } \\
\text { variables } \\
\text { ns owned } \\
\text { online }\end{array}$ \\
\hline
\end{tabular}

Table 5 shows three main results. Firstly, all regional and provincial museums confirm the inaccessibility for PWDs; in other words, these museums show a perfect correspondence between the actual accessibility and what is claimed online. Secondly, if a municipality owns a museum, the probability that the online information is correct increases by $122 \%$. Thirdly, as the regression II shows, in the case of public museums, the probability of false information decreases by $62 \%$. Overall, compared to private and ecclesiastical museums, public museums, especially municipal, provincial and regional ones show a higher quality of online information, in addition to a higher amount of information dedicated to PWDs which emerged in Section $3^{5}$.

\section{Conclusions}

This paper has studied the online information strategies adopted by museums in Tuscany in relation to PWDs. The empirical analysis of online data regarding 585 
museums shows that information on accessibility is, broadly speaking, scarce and inadequate. A clear result is that public museums provide more information regarding PWDs, compared to private and ecclesiastical museums. In particular, municipal, provincial and regional museums perform significantly better in terms of information on accessibility. Regarding museum categories, the information available provided by museums located within archaeological sites is scarce. Finally, the information devoted to PWDs presents a positive correlation with ticket rates, provincial income per capita, whether a museum has its own website, and number of ancillary services (for example, parking and bookshops). The last result regards the reliability of the online information. Assuming that a lack of information means that the museums are inaccessible to PWDs, a telephone survey showed that (in)accessibility has a higher probability of being confirmed in the case of public-owned museums.

Overall, these findings suggest that PWDs are underrepresented. The lack of online information on accessibility and assistance for PWDs does not necessarily mean that tourism facilities are completely devoid of such services. However, the lack of information is regrettable in itself, because PWDs have higher travel costs than ablebodied persons (Blichfeldt and Nicolaisen, 2011) and tend to live, on average, in lower income families (Figueiredo, Eusébio, and Kastenholz, 2012). Choosing a destination that does not provide information on accessibility means that PWDs face the risk of a wasted journey with additional costs and psychological frustration.

The empirical analysis of this paper has some limitations. Firstly, we did not investigate the question of accessibility to websites (Cunliffe, Kritou and Tudhope, 2001; Bowen 2003; Williams, Rattray and Grimes, 2006; Mills, Han, and Clay, 2008; Xiong, Cobanoglu, Cummings, and DeMicco, 2009; Dominguez Vila, Alen Gonzalez and Darcy, 2017), an important issue given the growing recourse of citizens (with or without disabilities) to the internet while planning the trip (Sarraf, 1999; Kravchyna and Hastings, 2002; Pekarik, 2003).

Secondly, we proposed a quantitative analysis and did not analyze the content of websites in terms of text and imagery (Collinson, Dunne, and Woolhouse, 2012; Cloquet at al., 2017). Section 2 highlighted that imagery regarding disability is completely absent on museum websites. However, such topics merit a future analysis given the increasing interest of tourism scholars in the content analysis of websites. Finally, we only considered the supply side of tourism accessibility: the accessibility for PWDs to museums in Tuscany and the online presentation of such information. 
However, the demand side cannot be ignored ${ }^{6}$. In fact, the museums' awareness of accessibility and marketing strategies designed for PWDs does not necessarily enhance the degree of inclusion of PWDs in the tourism industry. The perception of PWDs and their families in response to the communication strategies of tourism sites is equally important in terms of effective practices of social inclusion. Therefore, future research should address the links between web communication, information regarding PWDs and consumer responses. These themes will gain increasing importance, because internet usage for tourism purposes is set to grow even more in the near future (EUROSTAT, 2016).

The empirical findings of this paper have a clear relationship with the legislation and public policies aimed at ensuring institutional representativeness and social inclusion for disadvantaged people, such as PWDs. The European Union adopted a European Disability Strategy in 2010 (European Commission, 2010), which has several goals including the removal of "barriers to equal participation in public life and leisure activities". The European Commission also proposed a European Accessibility Act in late 2012 (at the time of writing, the Act was still in negotiation between the Commission, Parliament and Council; see European Commission, 2015). The Act would establish the harmonization of accessibility standards within the European Union. At the national level, the Italian Parliament approved the Code of Tourism in 2010 (legislative decree 23 may 2011, n. 79). The Code regulates the tourism sector at the state level and adapts current norms to international and European laws. Article 3 of the Code stated that the central state "ensures that persons with disabilities (...) can fully enjoy tourism resources, in complete autonomy, with the same service quality as other users and without price increase (...)". However, the Corte Costituzionale (the highest court of Italy in matters of constitutional law) declared in 2012 that Article 3 of the Code was unconstitutional, being in conflict with the principles of local autonomy and decentralisation. In fact, the matter of accessible tourism in Italy is subject to the exclusive competencies of the regional authorities. In December 2016, the regional council of Tuscany approved the "Unique Text of Regional Touristic System" (regional law 20 December 2016, n. 86). Articles 2 and 3 of the Text have recovered the parts of the Code of Tourism that had been cancelled by the Corte Costituzionale. However, at the time of writing this legislation had still not been implemented.

The website of the regional government of Tuscany reads: “(...) Tuscany presents very advanced social and health policies, in particular as regards the protection of elderly 
people and persons with disabilities" (Regione Toscana, 2016). Compared to other Italian and European regions, Tuscany is probably ahead in terms of policies devoted to PWDs. However, the results of this paper show that legislation and policies developed along the lines of the Convention on the Rights of Persons with Disabilities of United Nations (2006), as well as the regulations that should implement such policies, are still far from achieving visible results in terms of tourism accessibility for PWDs. Public museums perform significantly better, compared to non-public institutions, in informing PWDs about the relevant characteristics of the place of interest. However, the majority of public-owned museums still fail to provide an accurate description of the accessibility or inaccessibility for PWDs. 


\section{References}

Benhamou, F. (1998) 'The contradictions of deestatization: Museums in France'. in P. Boorsma, Van Hemel, A and, \& van der Wielen, N. (Eds.) Privatization and Culture: Experiences in the Arts, Heritage and Cultural Industries in Europe. Kluwer, Dordrecht.

Bertacchini, E.E., Dalle Nogare, C. and Scuderi, R. (2018) 'Ownership, organization structure and public service provision: the case of museums'. Journal of Cultural Economics, No. 42, pp.1-25.

Bieger, T. and Laesser, C. (2004) 'Information sources for travel decisions: Toward a source process model', Journal of Travel Research, Vol. 42, No. 4, pp. 357-371.

Blichfeldt, B. S. and Nicolaisen, J. (2011) 'Disabled travel: not easy, but doable', Current Issues in Tourism, Vol. 14, No. 1, pp. 79-102.

Bowen, J. P. (2003) 'Web access to cultural heritage for the disabled'. arXiv preprint cs/0307068.

Buhalis, D. and Darcy, S. (Eds.). (2010) Accessible Tourism: Concepts an Issues, Channel View Publications, Bristol.

Buhalis, D., Darcy, S. and Ambrose, I. (Eds.). (2012) Best Practice in Accessible Tourism: Inclusion, Disability, Ageing Population and Tourism (Vol. 53), Channel View Publications, Bristol.

Clear, M. (Ed.) (2000) Promises Promises: Disability and Terms of Inclusion, Federation Press, Annandale.

Cloquet, I., Palomino, M., Shaw, G., Stephen, G. and Taylor, T. (2017) ‘Disability, social inclusion and the marketing of tourist attractions', Journal of Sustainable Tourism, Vol. 26, No. 2, pp. 1-17.

Collinson, C., Dunne, L. and Woolhouse, C. (2012) 'Re-visioning disability and dyslexia down the camera lens: interpretations of representations on UK university websites and in a UK government guidance paper', Studies in Higher Education, Vol. 37, No. 7, pp. 859-873.

Cunliffe, D., Kritou, E. and Tudhope, D. (2001) 'Usability evaluation for museum web sites'. Museum Management and Curatorship, Vol. 19, No. 3, pp. 229-252.

Darcy, S. (2001) 'People with physical disabilities and leisure', in Celebrating Inclusion and Diversity in Leisure, pp. 59-80, HM Leisure Planning Pty Ltd, Melbourne. 
Darcy, S. (2002) 'Marginalized participation: Physical disability, high support needs and tourism', Journal of Hospitality and Tourism Management, Vol. 9, No. 1, pp. 61-73.

Darcy, S. and Taylor, T. (2009) 'Disability citizenship: An Australian human rights analysis of the cultural industries', Leisure Studies, Vol. 28, No. 4, pp. 419-441.

Darcy, S., Cameron, B. and Pegg, S. (2010) 'Accessible tourism and sustainability: A discussion and case study', Journal of Sustainable Tourism, Vol. 18, No. 4, pp. 515537.

Darcy, S., Cameron, B. and Schweinsberg, S. (2012) 'Accessible tourism in Australia', in Best Practice in Accessible Tourism: Inclusion, Disability, Ageing Population and Tourism (Vol. 53), pp. 79-98, Channel View Publications, Bristol.

Domínguez Vila, T., Alén González, E. and Darcy, S. (2017) 'Website accessibility in the tourism industry: an analysis of official national tourism organization websites around the world', Disability and Rehabilitation, August, pp. 1-12.

Eichhorn, V., Miller, G., Michopoulou, E. and Buhalis, D. (2008) 'Enabling access to tourism through information schemes?', Annals of Tourism Research, Vol. 35, No. 1, pp. 189-210.

European Commission (2010) 'European disability strategy: A renewed commitment to a barrier-Free Europe', available at https://ec.europa.eu/social/main.jsp?catld=1137. European Commission (2015) 'Proposal for a Directive of the European Parliament and of the Council on the approximation of the laws, regulations and administrative provisions of the Member States as regards the accessibility requirements for products and services'. Available at https://eur-lex.europa.eu/legalcontent/EN/TXT/?uri=COM:2015:0615:FIN.

EUROSTAT (2016) 'Statistics on ICT use in tourism', available at https://ec.europa.eu/eurostat/statisticsexplained/index.php/Statistics_on_ICT_use_in_tourism.

EUROSTAT (2019) 'Products-eurostat-news', available at https://ec.europa.eu/eurostat/web/products-eurostat-news/-/DDN-20190821-1.

Figueiredo, E., Eusébio, C. and Kastenholz, E. (2012) 'How diverse are tourists with disabilities? A pilot study on accessible leisure tourism experiences in Portugal', International Journal of Tourism Research, Vol. 14, No. 6, pp. 531-550.

Finch, S. (1979) 'Social tourism: The disabled tourist', in Proceedings of Workshop on Countryside for the Disabled, Keswick, 7-10. 
Fodness, D. and Murray, B. (1997) 'Tourist information search', Annals of Tourism Research, Vol. 37, No. 2, pp. 108-119.

Frey, B. S. and Pommerehne, W.W. (1989) Muses and Markets: Explorations in the Economics of the Arts, Basil Blackwell, Oxford.

Frey, B.S. and Meier, S. (2006) 'The economics of museums', in Handbook of the Economics of Art and Culture, Vol, 1, pp. 1017-1047, North-Holland, Amsterdam.

Frey, B.S. and Meier, S. (2011) 'Cultural economics', in A Companion to Museum Studies, pp. 398-414, John Wiley and Sons, London.

Gursoy, D., and McCleary, K. W. (2004) 'An integrative model of tourists' information search behavior', Annals of tourism research, Vol. 31, No. 2, pp. 353-373.

International Council of Museums (2018) 'Museum definition', available at http://icom.museum/the-vision/museum-definition.

Kastenholz, E., Eusébio, C. and Figueiredo, E. (2015) 'Contributions of tourism to social inclusion of persons with disability', Disability and Society, Vol. 30, No. 8, pp. 1259-1281.

Kravchyna, V. and Hastings, S. K. (2002) Informational value of museum web sites. First Monday, Vol.7, No. 2.

Lee, B.K., Agarwal, S. and Kim, H.J. (2012) 'Influences of travel constraints on the people with disabilities' intention to travel: An application of Seligman's helplessness theory', Tourism Management, Vol. 33, No. 3, pp. 569-579.

Lisney, E., Bowen, J. P., Hearn, K., \& Zedda, M. (2013) 'Museums and technology: Being inclusive helps accessibility for all'. Curator: The Museum Journal, Vol. 56, No. 3,pp. 353-361.

MIBACT (2018) 'Tutti i numeri dei musei italiani', available at http://www.beniculturali.it/mibac/export/MiBAC/sitoMiBAC/Contenuti/visualizza_asset.html_249254064.html

Mills, J.E., Han, J.H. and Clay, J.M. (2008) 'Accessibility of hospitality and tourism websites: a challenge for visually impaired persons', Cornell Hospitality Quarterly, Vol. 49, No. 1, pp. 28-41.

OECD (2015) OECD Digital Economy Outlook 2015, OECD Publishing, Paris.

O'Hagan, J.W. (1995) 'National museums: to charge or not to charge?', Journal of Cultural Economics, Vol. 19, No. 1, pp. 33-47.

Oliver, M. and Barnes, C. (2010) 'Disability studies, disabled people and the struggle for inclusion', British Journal of Sociology of Education, Vol. 31, No. 5, pp. 547-560. 
Packer, T.L., Mckercher, B. and Yau, M.K. (2007) 'Understanding the complex interplay between tourism, disability and environmental contexts', Disability and Rehabilitation, Vol. 29, No. 4, pp. 281-292.

Pekarik, A. J. (2003) Museum Web Sites. Curator: The Museum Journal, 46(3), 276278.

Poria, Y., Reichel, A. and Brandt, Y. (2009) 'People with disabilities visit art museums: an exploratory study of obstacles and difficulties', Journal of Heritage Tourism, Vol. 4, No. 2, pp. 117-129.

Regione Toscana (2016) 'Toscana accessibile - diritti', available at http://open.toscana.it/web/toscana-accessibile/normativa-regionale.

Regione Toscana (2017) 'Movimento turisti nelle strutture ricettive e struttura dell'offerta: dati 2016', available at http://www.regione.toscana.it/statistiche/datistatistici/turismo.

Sarraf, S. (1999) 'A survey of museums on the web: Who uses museum websites?'. Curator: The Museum Journal, Vol. 42, No. 3, pp. 231-243.

Schriner, K. (2001) 'A disability studies perspective on employment issues and policies for disabled people: An international view', in Handbook of disability studies, pp. 642662, Sage Publications, Thousand Oaks.

Schuster, J.M. (1998) 'Neither public nor private: the hybridization of museums', Journal of cultural economics, Vol. 22, No. 2-3, pp. 127-150.

Shelton, E.J. and Tucker, H. (2005) 'Tourism and disability: issues beyond access', Tourism Review International, Vol. 8, No. 3, pp. 211-219.

Stumbo, N.J., Wang, Y. and Pegg, S. (2011) 'Issues of access: what matters to people with disabilities as they seek leisure experiences', World Leisure Journal, Vol. 53, No. 2, pp. 91-103.

United Nations (2016) 'Report on the World Social Situation', available at https://www.un.org/development/desa/disabilities/.

Vogt, C.A. and Fesenmaier, D.R. (1998) 'Expanding the functional information search model', Annals of Tourism Research, Vol. 25, No.3, pp. 551-578.

Williams, R., Rattray, R. and Grimes, A. (2006) 'Meeting the on-line needs of disabled tourists: an assessment of UK-based hotel websites', International Journal of Tourism Research, Vol. 8, No. 1, pp. 59-73. 
Xiong, L., Cobanoglu, C., Cummings, P. and DeMicco, F. (2009) 'Website accessibility of US based hospitality websites', in Information and Communication Technologies in Tourism 2009, pp. 273-284, Springer, Vienna.

Yau, M. KS., McKercher, B. and Packer, T.L. (2004) 'Traveling with a disability: More than an access issue', Annals of Tourism Research, Vol. 31, No. 4, pp. 946-960.

1 According to the International Council of Museums (2018), a museum is a "non-profit, permanent institution in the service of society and its development, open to the public, which acquires, conserves, researches, communicates and exhibits the tangible and intangible heritage of humanity and its environment for the purposes of education, study and enjoyment." The empirical analysis of this paper also considers private museums that may be profit oriented.

2 According to Eurostat (2019), " $50 \%$ of internet users said that they booked their holiday accommodation or travel via the internet" in 2018, with the highest shares in Luxembourg $(73 \%)$, Finland (65\%) and Germany (64\%).

${ }^{3}$ Within each of the 20 Italian regions, there are provinces, each with its own provincial capital. Within each province, there are municipalities. Therefore, regions, provinces and municipalities are, respectively, administrative divisions of first, second and third levels.

${ }^{4}$ However, Cloquet et al. (2017) found that brochures and websites of the Cornwall attractions' represent PWDs inadequately.

${ }^{5}$ The results of Section 4 would be reversed if we assume that the absence of online information regarding PWDs means that museums are accessible. However, this assumption is questionable: in fact, more than $85 \%$ of the contacted museums confirmed the inaccessibility for PWDs.

${ }^{6}$ Broadly speaking, several studies have analyzed the perceptions of PWDs regarding the general obstacles encountered while travelling (see, for example, Stumbo, Wang and Pegg, 2011 and Lee, Agarwal and Kim, 2012), while others have considered the impressions of PWDs regarding the main accessibility problems during museum visits (Poria, Reichel and Brandt, 2009; Lisney et al., 2013). 